\title{
Technical Analysis on Household-Scale Rooftop Solar Power Plant Design with On-Grid System in Semarang City
}

\author{
Jaka Windarta ${ }^{1,2 *}$, Singgih Saptadi ${ }^{3}$, Denis $^{2}$, Dimas Adi Satrio ${ }^{2}$, Johanes Soritua Silaen $^{2}$ \\ ${ }^{1}$ School of Postgraduate Studies, Diponegoro University, Semarang-Indonesia \\ ${ }^{2}$ Department of Electrical Engineering, Faculty of Engineering, Diponegoro University, Semarang- \\ Indonesia \\ ${ }^{3}$ Department of Industrial Engineering, Faculty of Engineering, Diponegoro University, Semarang- \\ Indonesia
}

\begin{abstract}
Indonesia has $442 \mathrm{GW}$ total of potential renewable energy equivalence which can be used for electricity generation. However, the energy utilization in 2018 is only $8.8 \mathrm{GW}$ or $0.019 \%$ of total potential renewable energy, while the biggest renewable energy potential is at 207.8 GWp. By also considering the growing number of household customers, utilizing the rooftop as the base of solar power plant generators can be an effective and efficient solution. The purposes of this research are to technically design and analyze the household-scale rooftop solar power plant potential with an on-grid system. Through the utilization of PVSyst 6.43 software and a variety of main components, this household-scale rooftop solar power plant potential performance planning is expected to generate $4.23 \mathrm{kWh} / \mathrm{kWp}$ per day.
\end{abstract}

Keywords: Solar power plant; On-grid; Technical and Economic Analysis; PVSyst 6.43

\section{Introduction}

The demand for electricity has always grown from time to time compared to other energies. The electricity demand is projected to meet $2.214 \mathrm{TWh}$ in 2050 , or it can be said that the demand will increase for about 9 times from the electricity demand in 2018 in the amount of $254,6 \mathrm{TWh}$. The growth rate of electricity demand may reach an annual average score of $7 \%$ over the 2018-2050. The electricity demand during the projection period is relatively common with the largest portion of the household sector, industrial sector, commercial sector, transportation sector, and other sectors. The share of household electricity sector will increase from $49 \%$ in 2018 to $58 \%$ in 2050 . This condition is primarily affected by the household growth number which may increase from 67 million in 2018 to approximately 80 million in 2050 [1]. To meet the electricity demand which has increased 9 times from 2018 ,

* Corresponding author: jakawindarta@lecturer.undip.ac.id 
in 2050, the electricity production will reach $2.562 \mathrm{TWh}$. The decrease in fossil energy production especially petroleum and global commitments in reducing greenhouse and gas emission has driven the Indonesian government to intensify important and sustainable roles in new and renewable energy as part of maintaining energy autonomy and endurance. In accordance with PP regulation number 79 of 2014 concerning the National Energy Policy, the targetted new and renewable energy combination in 2025 is at least $23 \%$ and in 2050 is at least $31 \%$. Indonesia has big potency on new and renewable energy which will be achievable and meet the primary target [1]. Indonesia has a total renewable energy potential equivalent to $442 \mathrm{GW}$ which can be used for electricity generation, whereas the utilization is only $8.8 \mathrm{GW}$ or it is only $0.019 \%$ of the total renewable energy in 2018 . The biggest potential for renewable energy may come from solar energy at $207.8 \mathrm{GWp}$. To accelerate New and Renewable energy development, the government has established several regulations such as Peraturan Presiden No. 4 in 2016 (Article 14) concerning the Electricity Infrastructure Acceleration prioritizing the use of new and renewable energy [2], Peraturan Menteri ESDM No. 50 in 2017 concerning the Utilization of Renewable Energy Sources as the Supply of Electricity [3], and Peraturan Menteri ESDM No. 49 in 2018 concerning the Use of Rooftop Solar Power Generation System by state-owned corporation Perusahaan Listrik Negara (PLN) customers [4]. With the high potential of solar energy in Indonesia and the indorsement from government regulations, this system is expected to be a solution to comply with the high electricity demand in the future by utilizing the solar cell as the source of electrical energy. Solar Power Plant or Pembangkit Listrik Tenaga Surya (PLTS) is one of the examples of the renewable energy application by taking advantage of the sun as the primary energy source. By considering the growing number of household customers, utilizing the rooftop's consumers as solar power generator base can be an effective and efficient solution. Therefore, the purpose of this research is to analyze technical feasibility of rooftop solar power plant system with a household-scale on-grid system by the PVSyst 6.43 software utilization.

\section{Theoretical Background}

\subsection{Solar Radiation}

Solar radiation is defined as the amount of energy received per unit area and time on earth. The value can be determined depending on such factors, for instance, the location latitude, the season and weather, and the timing [5]. There are two types of radiation which are direct radiation generated from the sun, and indirect radiation generated from atmospheric particles scattering. Indonesia is geographically located on the equator in exact and this resulting in such advantages and great potential of solar energy utilization [6]. Indonesia has a relatively high radiation level which is equal to $4.80 \mathrm{kWh} / \mathrm{m} 2 /$ day [7].

\subsection{Solar Power Plants}

Solar Power Plant is a sunlight-based power plant that uses solar cells to convert the photon sunray radiation into electricity. Solar cells are made from sheer layers of pure silicon and such semiconductor materials [8]. Solar Power Plants is friendly to the environment and it does not produce any noise nor harmful waste to the surroundings. There are several factors that influence the solar cell output power efficiency such as solar radiation, solar cell temperature, solar panel orientation, and shadow leverages [9]. 


\subsection{Technical Analysis}

The technical analysis is conducted based on the rooftop solar power plant capacity, major components specification utilization and determination, solar panel orientation, and the generated power from the plant. The power generated by rooftop solar power plant is affected by some factors including sunray radiation in the research area, the solar panel slope and its direction, sunlight, temperature, and the technical performance. This technical performance is predicted to decrease in time because of the solar module degradation. The quality of rooftop solar power plant can also be seen by its performance ratio. In general, performance ratio is shown in percentage value that shows the total power produced by the system and also the losses compared while the system is working in STC condition. Solar power plant losses are due to solar panel efficiency, temperature, and inverter efficiency [10].

\section{Simulation, Result, and Analysis}

\subsection{Simulation}

To stimulate the solar power plant prototype design on PVSyst 6.43 , such data are required, for instance, the factors that affect PVSyst 6.43 software simulation result. The factors are including the solar power plant geographic location, solar energy potential data, the temperature, the radiation spread, wind speed, solar panel orientation in the spot, specifications of the components used, and the daily load estimation. After the simulation process is conducted, the amount of potential electrical energy will be shown by the rooftop solar power plant in the research area. There are numerous values that indicate the amount of produced electrical power, the amount of electricity delivered to the load, and the amount of electric power supplied to the grid. In addition, the solar power plant loss diagram and performance will be shown in graphical data. In this research, a household-scale rooftop solar power plant is designed in Sambiroto Asri Cluster residence number A9 in Semarang City, Indonesia.

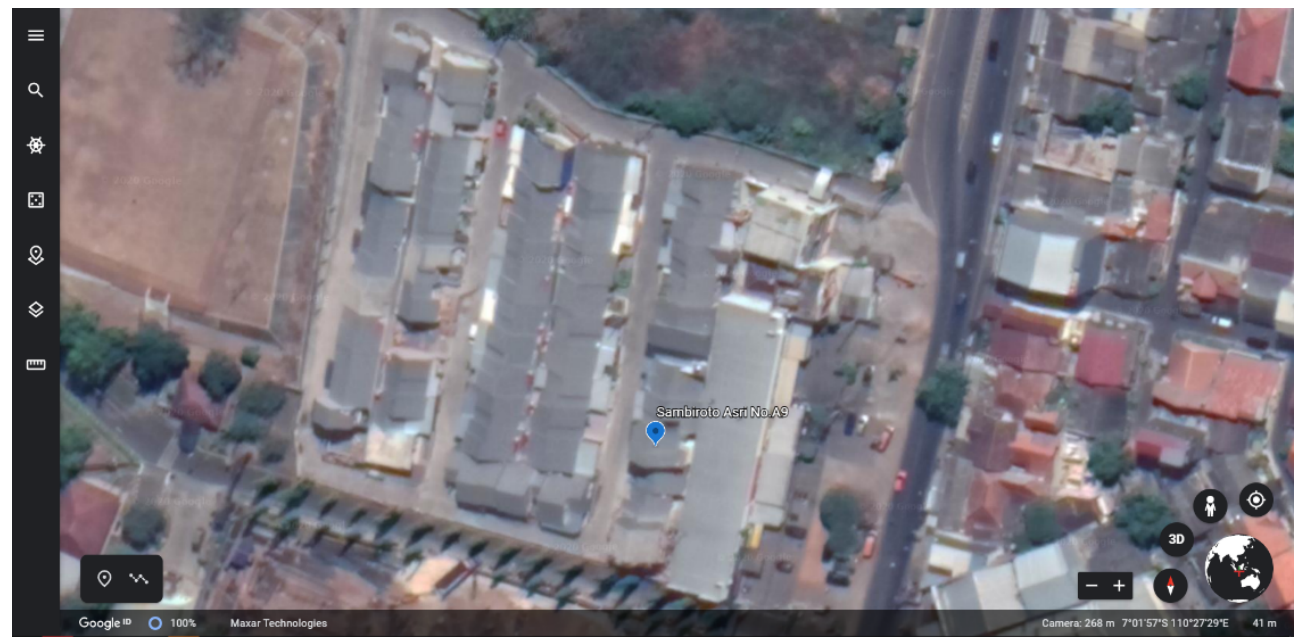

Fig. 1. Research Location in Sambiroto Asri Cluster residence number A9, Semarang City

The research area is located astronomically in $7^{\circ} 1^{\prime} 56.06 "$ South Latitude and $110^{\circ} 27^{\prime} 28.58^{\prime \prime}$ East Longitude. According to NASA Prediction of Worldwide Energy Resources data [11], sun insolation in 2019 in this area is $5,59 \mathrm{kWh} / \mathrm{m} 2 /$ day. Moreover, data 
generated from NASA Prediction of Worldwide Energy Resources shows the diffuse radiation and wind velocity, also Semarang city temperature data is generated from Semarang-based Station Meteorology, Climatology, and Geophysical Agency. The data mentioned above can be used to generate the result of potential solar energy usage into a rooftop solar power plant in the research area.

Table 1. Insolation, Temperature, Diffuse Radiation, and Wind Velocity in Semarang City.

\begin{tabular}{|c|c|c|c|c|}
\hline Month & $\begin{array}{c}\text { Insolation } \\
\left(\mathbf{k W h} / \mathbf{m}^{\mathbf{2}} \mathbf{. d a y}\right)\end{array}$ & $\begin{array}{c}\text { Temperature } \\
\mathbf{(} \mathbf{~} \mathbf{C})\end{array}$ & $\begin{array}{c}\text { Diffuse Radiation } \\
\left.\mathbf{( k W h} / \mathbf{m}^{\mathbf{2}} \mathbf{. d a y}\right)\end{array}$ & $\begin{array}{c}\text { Wind Velocity } \\
\mathbf{( m / \mathbf { s } )}\end{array}$ \\
\hline January & 4,60 & 27,6 & 2,33 & 2,59 \\
\hline February & 5,29 & 27,9 & 2,39 & 1,42 \\
\hline March & 4,55 & 27,6 & 2,32 & 2,06 \\
\hline April & 5,08 & 28,7 & 2,06 & 1,76 \\
\hline May & 5,41 & 29,0 & 1,76 & 2,65 \\
\hline June & 5,14 & 28,3 & 1,62 & 2,82 \\
\hline July & 5,37 & 27,7 & 1,63 & 3,04 \\
\hline August & 5,94 & 28,0 & 1,80 & 3,11 \\
\hline September & 6,49 & 28,8 & 2,06 & 2,99 \\
\hline October & 6,54 & 29,8 & 2,31 & 2,75 \\
\hline November & 6,02 & 30,1 & 2,34 & 2,37 \\
\hline December & 5,30 & 28,7 & 2,32 & 1,42 \\
\hline
\end{tabular}

According to the real condition in the research area, the planning of the Rooftop Solar Power Plant utilizes a fixed tilted plane with such adjustment to the rooftop condition for about $30^{\circ}$ and azimuth $80^{\circ}$.

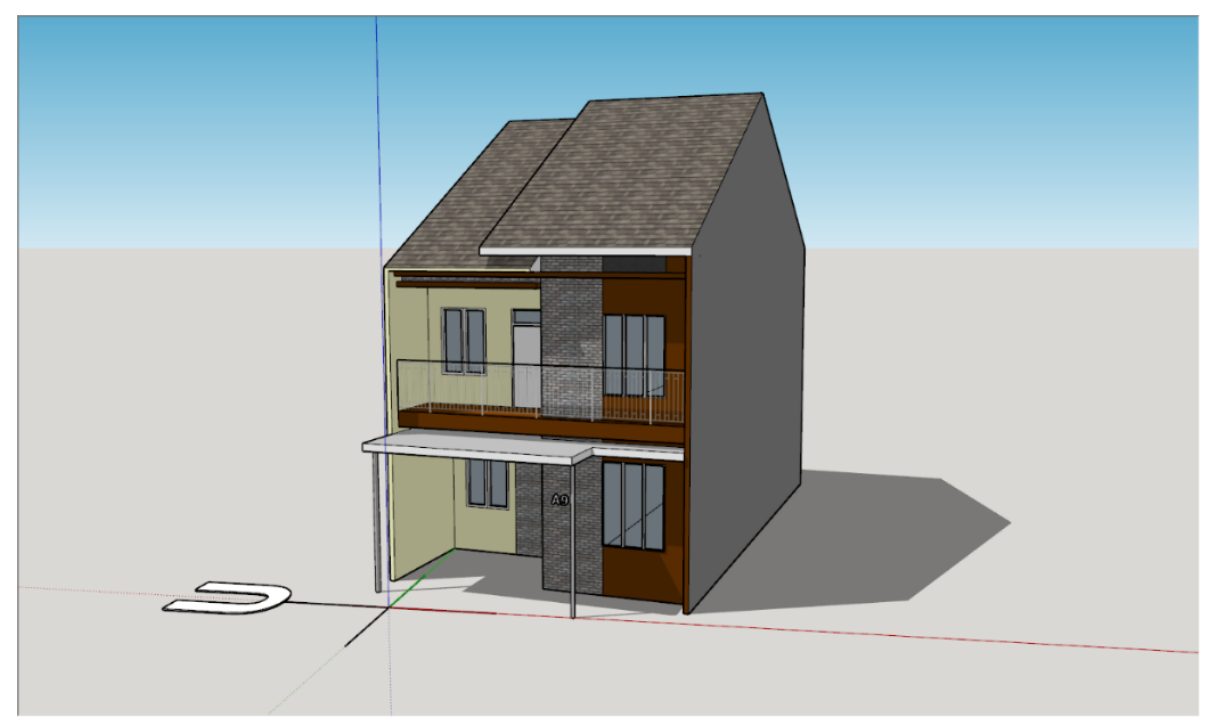

Fig. 2. Visualization in the Research Area Located in Sambiroto Asri Cluster Residence, Semarang city. 


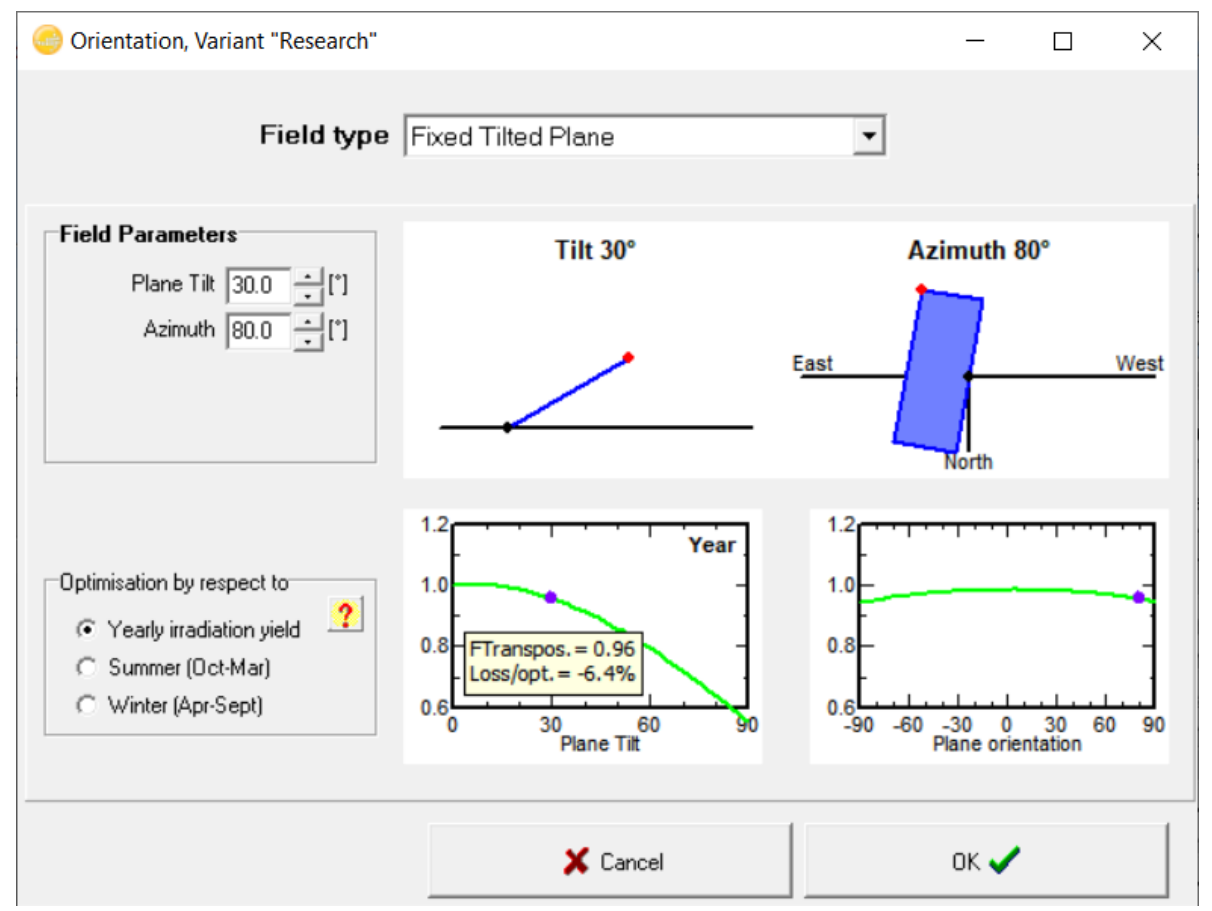

Fig. 3. Solar Module orientation

The major components are solar panels and inverters. Each component consists of two alternative options. Solar Panel alternative option is polycrystalline or monocrystalline solar panel with $405 \mathrm{Wp}$ capacity, while the inverter alternative option chosen for this research is an inverter with more than $97 \%$ efficiency. The alternative component options used for Solar Power Plant will be assigned into PVSyst 6.43 software and it will be stimulated in the Rooftop Solar Power Plant planning as explained below.

Table 2. Solar Panel Specification Variation 1 (Canadian Solar CS3W405P)

\begin{tabular}{|c|c|}
\hline Specification & Value \\
\hline Maximum Power (Pmax) & $405 \mathrm{Wp}$ \\
\hline Open Network Voltage (Voc) & $47,4 \mathrm{~V}$ \\
\hline Short Circuit Current (Isc) & $10,98 \mathrm{~A}$ \\
\hline Maximum Voltage (Vmp) & $38,9 \mathrm{~V}$ \\
\hline Maximum Current (Imp) & $10,42 \mathrm{~A}$ \\
\hline Efficiency Module & $18,3 \%$ \\
\hline Dimension (mm x mm x mm) & $2108 \times 1048 \times 40$ \\
\hline Price & $\mathrm{Rp} \mathrm{3.900.000}$ \\
\hline
\end{tabular}


Table 3. Solar Panel Specification Variaton 2 (Trina Solar TSM-405DE15M(II))

\begin{tabular}{|c|c|}
\hline Specification & Value \\
\hline Maximum Power (Pmax) & $405 \mathrm{Wp}$ \\
\hline Open Network Voltage (Voc) & $49,2 \mathrm{~V}$ \\
\hline Short Circuit Current (Isc) & $10,92 \mathrm{~A}$ \\
\hline Maximum Voltage (Vmp) & $40,5 \mathrm{~V}$ \\
\hline Maximum Current (Imp) & $10 \mathrm{~A}$ \\
\hline Efficiency Module & 19,9 \\
\hline Dimension (mm x mm x mm) & $2024 \times 1004 \times 35$ \\
\hline Price & $\mathrm{Rp} \mathrm{4.000.000}$ \\
\hline
\end{tabular}

Table 4. Inverter Specification Variation 1 (Solax X1-1.1-S)

\begin{tabular}{|c|c|}
\hline Specification & Value \\
\hline Input DC & $1250 \mathrm{~W}$ \\
\hline Maximum Solar Array Power & $400 \mathrm{~V}$ \\
\hline Maximum DC Voltage & $12 \mathrm{~A}$ \\
\hline Maximum Input Current & $55-380 \mathrm{~V}$ \\
\hline MPPT Voltage Range & $1100 \mathrm{~W}$ \\
\hline Output AC & $180-280 \mathrm{~V}$ \\
\hline Maximum Output Power & $5,5 \mathrm{~A}$ \\
\hline Grid Voltage Range \\
\hline Maximum Output Current \\
\hline General Data \\
\hline Maximum Efficiency & $97,1 \%$ \\
\hline Dimension & $267 \times 328 \times 116 \mathrm{~mm}$ \\
\hline Price & $\mathrm{Rp} 6.000 .000$ \\
\hline
\end{tabular}

Table 5. Inverter Specification Variation 2 (Solis 1000W)

\begin{tabular}{|c|c|}
\hline Specification & Value \\
\hline Input DC & $1200 \mathrm{~W}$ \\
\hline Maxiumum Solar Array Power & $600 \mathrm{~V}$ \\
\hline Maximum DC Voltage & $11 \mathrm{~A}$ \\
\hline Maximum Input Current & $50-500 \mathrm{~V}$ \\
\hline MPPT Voltage Range & $1100 \mathrm{~W}$ \\
\hline Output AC & $160-285 \mathrm{~V}$ \\
\hline Maximum Output Power & $5,2 \mathrm{~A}$ \\
\hline Grid Voltage Range \\
\hline Maximum Output Current & $97,2 \%$ \\
\hline General Data & $310 \times 373 \times 160 \mathrm{~mm}$ \\
\hline Maximum Efficiency & $\mathrm{Rp} \mathrm{5.500.000}$ \\
\hline Dimension &
\end{tabular}


According to component alternatives above, Rooftop Solar Power Plant that will be stimulated have four different configurations as shown in Table 6 below.

Table 6. Alternative Component Configuration of Rooftop Solar Power Plant

\begin{tabular}{|c|c|c|c|}
\hline Variation & Solar Panel & Inverter & $\begin{array}{c}\text { Array } \\
\text { Configuration }\end{array}$ \\
\hline 1 & $\begin{array}{c}\text { Canadian Solar Polycrystalline } \\
405 \mathrm{Wp} \\
\text { Voc }(47,4 \mathrm{~V}) \\
\text { Isc }(10,98 \mathrm{~A})\end{array}$ & $\begin{array}{l}\text { Solax X1-1.1-S } \\
\text { Max Vin }(400 \mathrm{~V}) \\
\text { Max Iin }(12 \mathrm{~A})\end{array}$ & $\begin{array}{c}3 \text { series of installed } \\
\text { modules } \\
\text { Voc }(142,2 \mathrm{~V}) \\
\text { Isc }(10,98 \mathrm{~A})\end{array}$ \\
\hline 2 & $\begin{array}{c}\text { Canadian Solar Polycrystalline } \\
405 \mathrm{Wp} \\
\text { Voc }(47,4 \mathrm{~V}) \\
\text { Isc }(10,98 \mathrm{~A}) \\
\end{array}$ & $\begin{array}{l}\text { Solis Mini-1000- } \\
4 \mathrm{G} \\
\text { Max Vin }(600 \mathrm{~V}) \\
\text { Max Iin }(11 \mathrm{~A}) \\
\end{array}$ & $\begin{array}{c}3 \text { series of installed } \\
\text { modules. } \\
\text { Voc }(142,2 \mathrm{~V}) \\
\text { Isc }(10,98 \mathrm{~A}) \\
\end{array}$ \\
\hline 3 & $\begin{array}{c}\text { Trina Solar Polycrystalline } \\
405 \mathrm{Wp} \\
\text { Voc }(49,2 \mathrm{~V}) \\
\text { Isc }(10,52 \mathrm{~A})\end{array}$ & $\begin{array}{l}\text { Solax X1-1.1-S } \\
\text { Max Vin }(400 \mathrm{~V}) \\
\text { Max Iin }(12 \mathrm{~A})\end{array}$ & $\begin{array}{c}3 \text { series of installed } \\
\text { modules. } \\
\text { Voc }(147,6 \mathrm{~V}) \\
\text { Isc }(10,52)\end{array}$ \\
\hline 4 & $\begin{array}{c}\text { Trina Solar Polycrystalline } \\
405 \mathrm{Wp} \\
\text { Voc }(49,2 \mathrm{~V}) \\
\text { Isc }(10,52 \mathrm{~A})\end{array}$ & $\begin{array}{l}\text { Solis Mini-1000- } \\
4 \mathrm{G} \\
\text { Max Vin }(600 \mathrm{~V}) \\
\text { Max Iin }(11 \mathrm{~A})\end{array}$ & $\begin{array}{c}3 \text { series of installed } \\
\text { modules. } \\
\text { Voc }(147,6 \mathrm{~V}) \\
\text { Isc }(10,52)\end{array}$ \\
\hline
\end{tabular}

Estimated daily load data in the research area is generated manually and periodically to obtain an exact daily load profile data. The research area has an installed electrical capacity of $1300 \mathrm{VA}$. The following table will display the daily load profile in the researh area.

Table 7. Daily Load Profile in the research area

\begin{tabular}{|c|c|c|c|c|}
\hline Load & Amount & Power (W) & $\begin{array}{c}\text { Time Length } \\
(\mathbf{h})\end{array}$ & Energy (Wh) \\
\hline Lamp & 10 & 10 & 12 & 1200 \\
\hline TV & 1 & 50 & 7 & 350 \\
\hline AC & 1 & 320 & 13 & 4160 \\
\hline Refrigerator & 1 & 100 & 24 & 2400 \\
\hline Washing Machine & 1 & 300 & 2 & 600 \\
\hline Laptop & 1 & 135 & 12 & 1260 \\
\hline Handphone & 1 & 5 & 12 & 60 \\
\hline
\end{tabular}

According to the Table 7, the daily load profile in the research area will be modified into hourly load profile as follows. 


\section{ICENIS 2020}

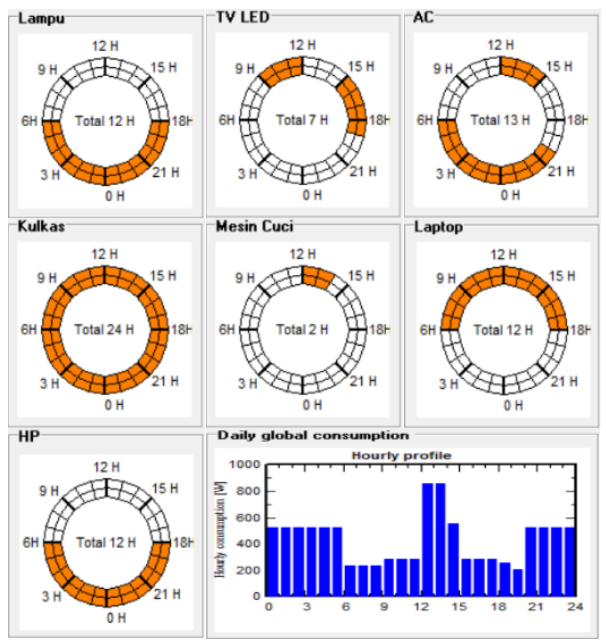

Fig. 4. Daily Load profile distribution in the research area.

The simulation utilizing PVSyst 6.43 software can be conducted after determining and inputting all data.

\subsection{Result}

The result of PVSyst 6.43 simulation on household-scale rooftop solar power plant planning variations $1,2,3$, and 4 can be seen in the figures below.

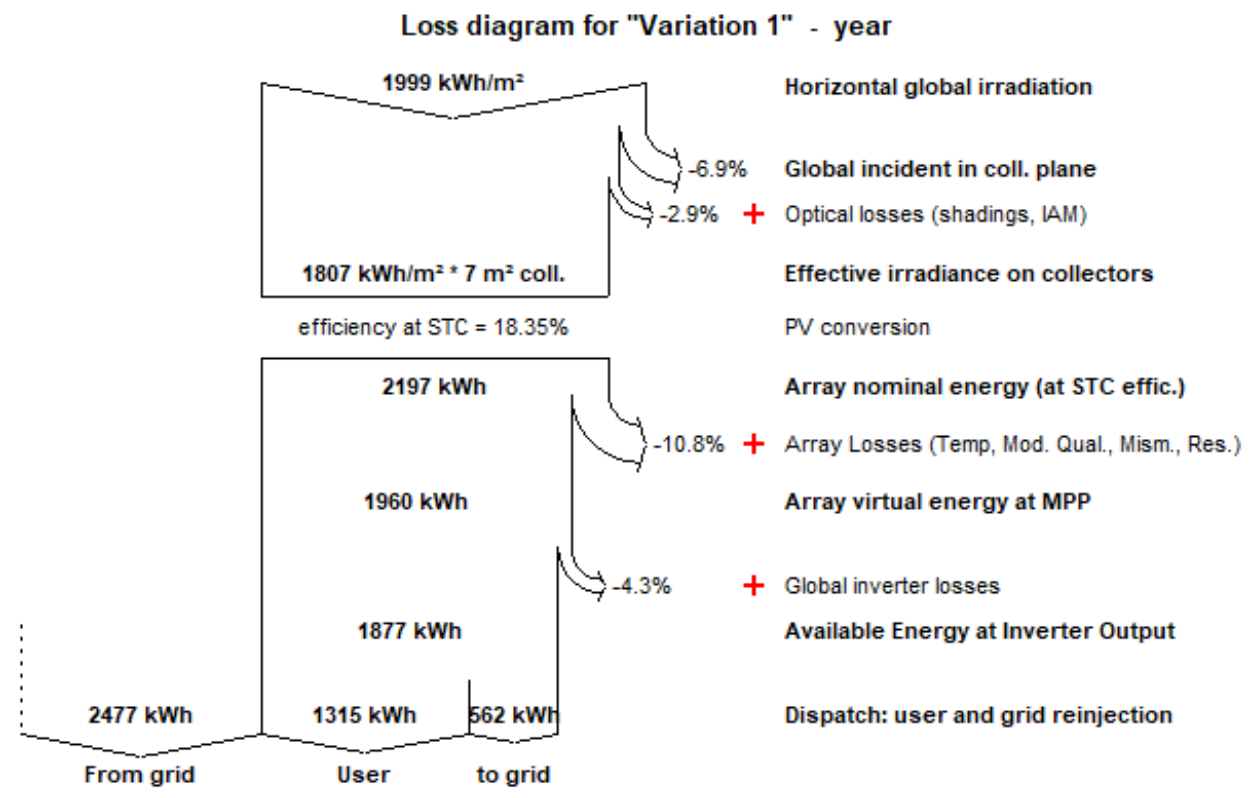

Fig. 5. Variation 1 Results 


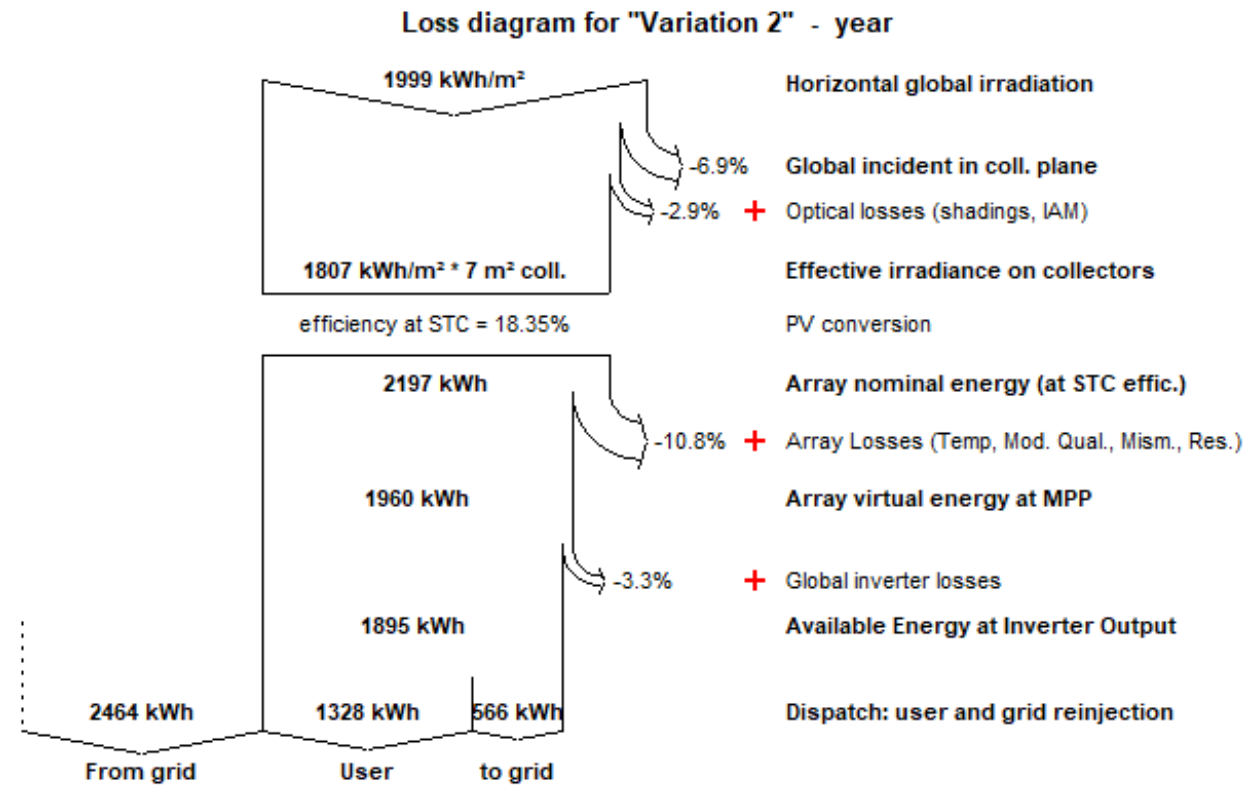

Fig. 6. Variation 2 Results

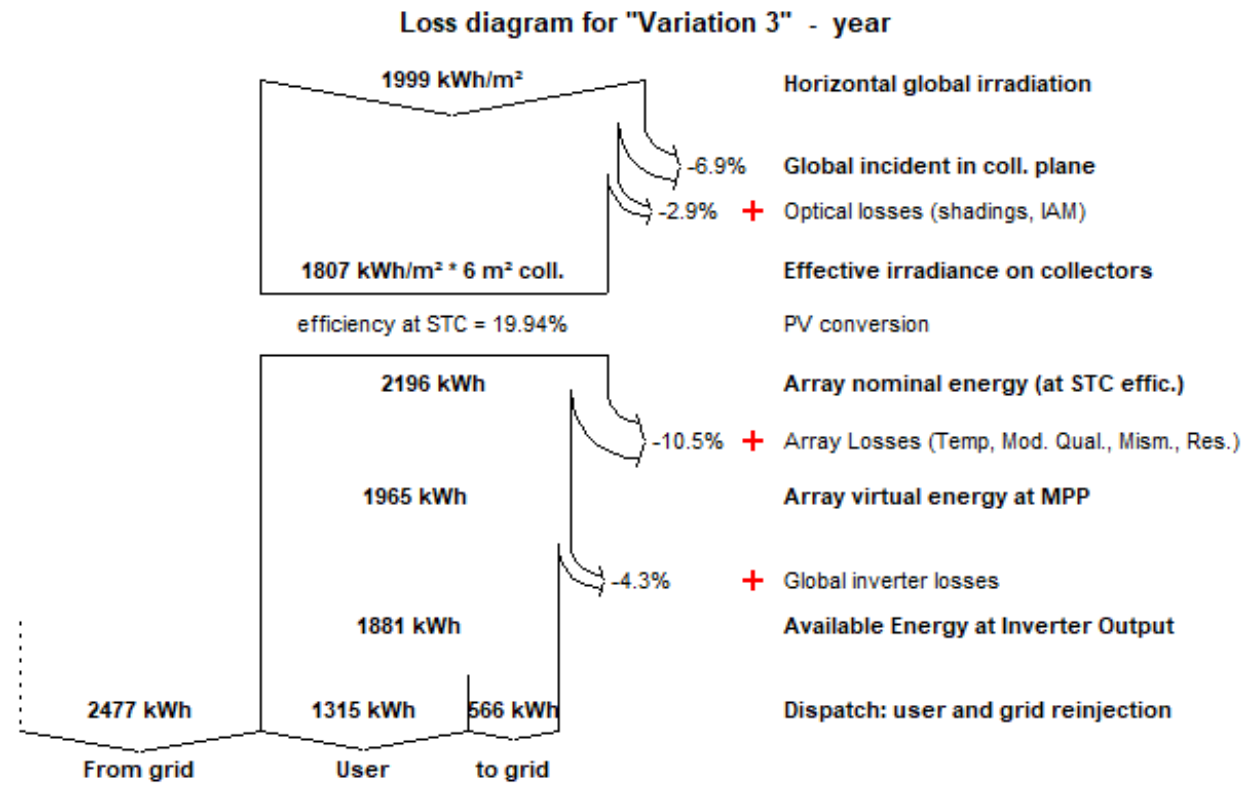

Fig. 7. Variation 3 Results 


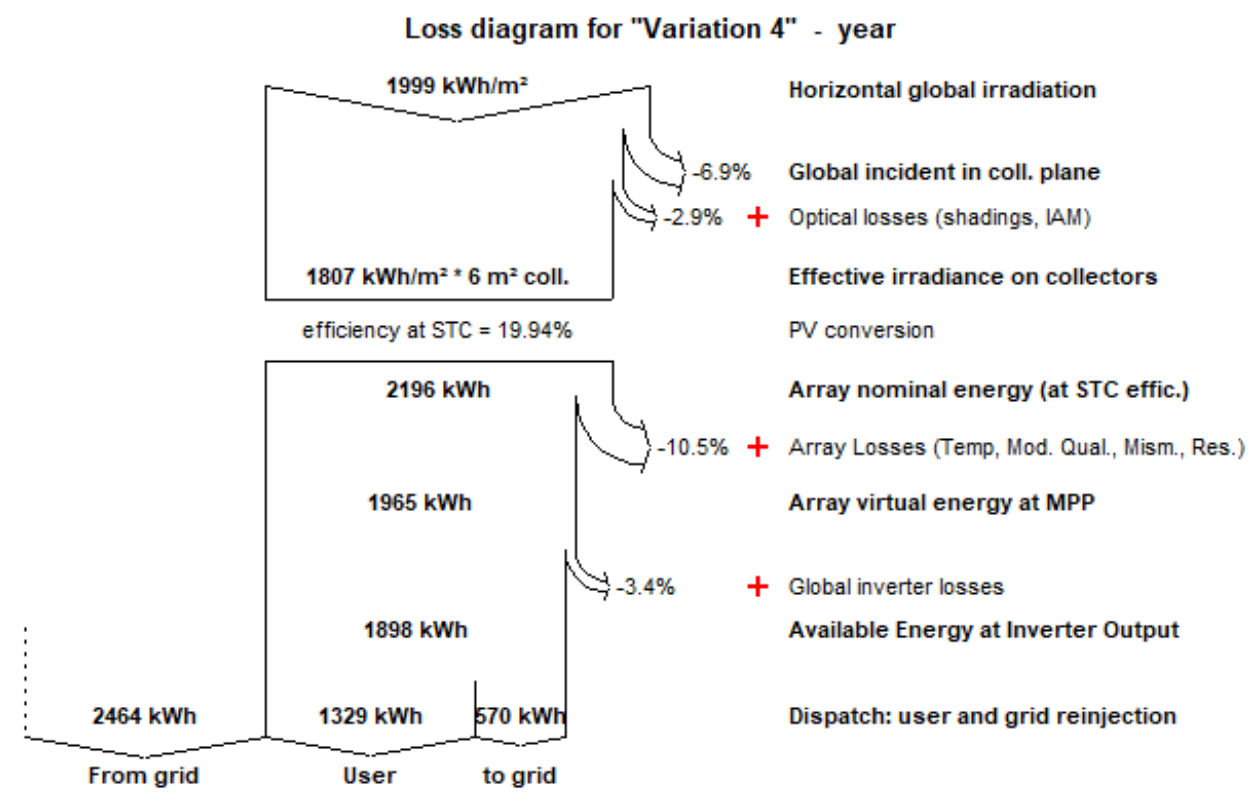

Fig. 8. Variation 4 Results

\subsection{Analysis}

Based on the simulation results of PVSyst 6.43 software household-scale rooftop solar power plant in the research area, Table 8 is aimed to calculate each variations as follows.

Table 8. The result of PVSyst 6.43 simulation in Rooftop Solar Power Plant Variation 1, 2, 3, and 4.

\begin{tabular}{|c|c|c|c|c|c|}
\hline Variation & $\begin{array}{c}\text { Solar } \\
\text { Panel } \\
\text { Insulation } \\
\left(\mathbf{k W h} / \mathbf{m}^{2}\right)\end{array}$ & $\begin{array}{c}\text { STC } \\
\text { Array } \\
\text { Electric } \\
\text { Energy } \\
\text { (kWh) }\end{array}$ & $\begin{array}{l}\text { Array } \\
\text { Output } \\
\text { Electric } \\
\text { Energy } \\
\text { (kWh) }\end{array}$ & $\begin{array}{c}\text { Inverter } \\
\text { Output } \\
\text { Electric } \\
\text { Energy } \\
\text { (kWh) }\end{array}$ & $\begin{array}{c}\text { Performance } \\
\text { Ratio (\%) }\end{array}$ \\
\hline $\begin{array}{c}\text { Variation } \\
1 \\
\end{array}$ & 1861,3 & 2197 & 1960 & 1877 & 83 \\
\hline $\begin{array}{l}\text { Variation } \\
2\end{array}$ & 1861,3 & 2197 & 1960 & 1894 & 83,8 \\
\hline $\begin{array}{l}\text { Variation } \\
3 \\
\end{array}$ & 1861,3 & 2196 & 1965 & 1881 & 83,2 \\
\hline $\begin{array}{c}\text { Variation } \\
4 \\
\end{array}$ & 1861,3 & 2196 & 1965 & 1898 & 83,9 \\
\hline
\end{tabular}

It can be concluded from Table 8 that the production sunray array electric energy production in variation 1 and 2 have bigger value in the amount of $2197 \mathrm{KWh}$ per year rather than the variation 3 and 4 which only equal to $2196 \mathrm{KWh}$ per year. Thus, it has $1 \mathrm{KWh}$ deviation caused by the solar panel efficiency and surface area used in this research. The variation 1 and 2 utilize Canadian Solar Panel type CS3W405P with an efficiency value of $18.3 \%$ and it has surface area of $6,63 \mathrm{~m}^{2}$ which produces electrical energy output array of $2197 \mathrm{KWh}$ during STC condition. On the other hand, the variation 3 and 4 utilize Trina Solar Panel type TSM-405DE15M(II) with an efficiency value of $19,9 \%$ and it has surface area of $6,09 \mathrm{~m}^{2}$ which produces electrical energy output array of $2196 \mathrm{KWh}$. Therefore, it can be 
concluded that the greater solar panel efficiency and the larger solar panel surface area will be resulting in better results. The efficiency is also depending on the type of solar panel. Monocrystalline solar panel types generally have better efficiency because the primary material for making panel which is silicone has greater concentration rather than the polycrystalline type [12]. However, at the same power position, monocrystalline types have smaller panel surface area than the polycrystalline types.

The annual array output for electrical energy in variation 1 and 2 suffered losses from STC conditions of $237 \mathrm{kWh}$ or $10.79 \%$ from the STC condition so it becomes $1960 \mathrm{kWh}$. Moroever, the annual array output for electrical energy in variation 3 and 4 suffered losses from STC conditions of $231 \mathrm{kWh}$ or $10,52 \%$ from the STC condition so it results of 1965 $\mathrm{kWh}$. It can be said that these solar panel types have similar losses characteristics for about $0.27 \%$ adrift.

If variation 1 and 2 is compared by also looking at the same sunray array, the output electric energy in variation 2 is larger than variation 1 . This due to the usage of Solis inverter MINI-1000-4G type which has efficiency rate of $97.2 \%$ in variation 2 is bigger than the usage of Solax inverter X1-1.1-S type which has efficiency rate of $97.1 \%$.

This also can be seen in variation 3 and 4 . The output electric energy in variation 4 is larger than variation 2. This due to the usage of Solis inverter MINI-1000-4G type which has efficiency rate of $97.2 \%$ in variation 2 is bigger than the usage of Solax inverter X1-1.1-S type which has efficiency rate of $97.1 \%$. Hence, it could be said that the inverter with a bigger efficiency produces a bigger electrical output as well.

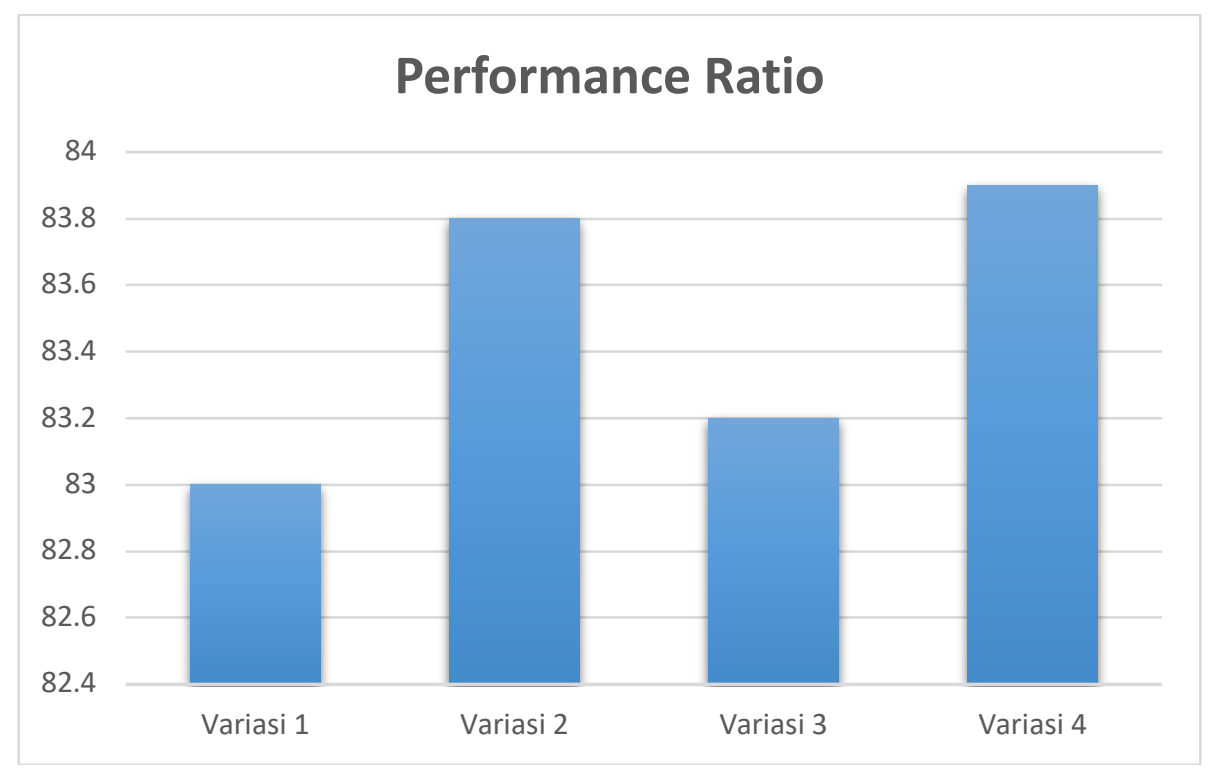

Fig. 9. Performance Ratio of household-scale rooftop solar power plant in research area.

It can be concluded that the variation with the biggest performance ratio is variation 4 which has an $83.9 \%$ ratio, and the smallest performance ratio is variation 1 which has an $83 \%$ ratio. 


\section{Conclusion}

The solar power plant system designed in this research is connected to the grid (on-grid system). The rooftop solar power plant planning has four different variations which utilizes 3 solar panels with a capacity of $405 \mathrm{Wp}$ and a $1000 \mathrm{~W}$ inverter. The electricity produced from this household-scale rooftop solar power plant in the research area is ranging from 1877$1898 \mathrm{kWh}$ with a performance ratio ranging from 83-83.9\%. Based on the performance ratio result, the most feasible variation is variation 4 with an $83.9 \%$ performance ratio value.

\section{References}

[1] S. Suharyati, S. H. Pambudi, J. L. Wibowo, and N. I. Pratiwi, Outlook Energi Indonesia 2019, (2019)

[2] President of the Republic of Indonesia, Presidential Regulation of the Republic of Indonesia Number 4 of 2016 concerning the Acceleration of Electricity Infrastructure Development. (2016)

[3] Minister of Energy and Mineral Resources of the Republic of Indonesia, Regulation of the Minister of Energy and Mineral Resources of the Republic of Indonesia Number 50 Year 2017 Concerning Utilization of Renewable Energy Sources for Electric Power Supply. (2017)

[4] Minister Of Energy And Mineral Resources Of The Republic of Indonesia, Regulation of the Minister of Energy and Mineral Resources Number 49 of 2018 Regarding the Use of Roof Solar Power Generation Systems by Consumers of PT. PLN (Persero). (2018)

[5] H. Dennis L, The Global Energy Balance, in Global Physical Climatology, 2nd ed., Elsevier, pp. 25-48. (2016)

[6] J. Windarta, Denis, A. Nugroho, and B. Bagaskoro, Design and Analysis of Technical Economics of Off-grid Systems Solar Power Plant Using Homer at Cemara Island, Brebes Regency, E3S Web Conf., vol. 125, no. 201 9, pp. 2-7, (2019)

[7] J. Windarta, A. Pratama, Denis, and A. Nugroho, Testing of Solar Power Plant Components Off-Grid Systems and Engineering Economic Analysis at Cemara Island, Brebes Regency, Indonesia, E3S Web Conf., vol. 125, no. 201 9, (2019)

[8] I. K. Agus Setiawan, I. N. Satya Kumara, and I. W. Sukerayasa, Performance Analysis Of Solar Electric Power Plant (PLTS) One MWp Interacted In grid In Kayubihi, Bangli, in Maj. Ilm. Teknol. Elektro, vol. 13, no. 1, pp. 27-33. (2014)

[9] D. L. King, W.E. Boyson, and J. Kratochvil, Analysis of Factors Influencing the Annual Energy Production of Photovoltaic Systems, in Conference Record of the Twenty-Ninth IEEE Photovoltaic Specialists Conference, pp. 1356-1361 (2002)

[10] Utility-Scale Solar Photovoltaic Power Plants a Project Developer's Guide. Washington, D.C., (2015)

[11] NASA Prediction of Worldwide Energy Resources. [Online]. Available: https://power.larc.nasa.gov/data-access-viewer/. [Accessed: 02-Jun-2020].

[12] A. Mohammad Bagher, Types of Solar Cells and Application, Am. J. Opt. Photonics, vol. 3, no. 5, p. 94, (2015) 